\title{
KOMUNIKASI JARAK JAUH RADIO VHF/UHF MENGGUNAKAN CROSS BAND REPEATER (XBR) DI KUBE PSP DESA KEMIRI KECAMATAN JABUNG MALANG
}

\author{
Choirul Saleh $^{1)}$, Eko Nurcahyo ${ }^{2)}$, Sidik Noertjahjono ${ }^{3)}$ \\ ${ }^{1,2)}$ Teknik Listrik, Fakultas Teknologi Industri, Institut Teknologi Nasional Malang \\ ${ }^{3)}$ Teknik Elektro, Fakultas Teknologi Industri, Institut Teknologi Nasional Malang \\ Email : choirulsaleh@lecturer.itn.ac.id
}

\begin{abstract}
Abstrak. Handy Talky (HT) merupakan salah satu perangkat komunikasi yang cepat dan mudah digunakan karena tidak perlu mengalami tunda waktu dalam proses pengolahan maupun pengiriman informasinya, namun dengan terbatasnya jarak jangkau, membuat pengguna merasa tertantang untuk meningkatkan jarak jangkau radio pada band VHF / UHF tersebut yang biasanya hanya menjangkau 2-5 km dengan power maksimum 5 watt. Komunikasi radio Unit Koperasi dengan kelompok usaha bersama peternak sapi perah (KUBE PSP) Desa Kemiri Kecamatan Jabung Malang sering mengalami gangguan dalam komunikasi dimana kedua lokasi ini tidak boleh terhambat oleh ruang dan waktu, sehingga dibangunlah Cross Band Repeater (XBR) untuk memperluas jangkauan hingga radius 40-100 km hanya dengan daya sekitar 100 - 300 mWatt sehingga menghemat penggunaan energy listrik dalam komunikasi radio. Cross Band Repeater adalah sistem perangkat repeater yang menggunakan dua band berbeda untuk input dan outputnya. Kebanyakan menggunakan band VHF dan UHF. Input dan output dapat dipakai berbalikan, misal input dari VHF dan memancar ulang di UHF dan sebaliknya. Keuntungan dari XBR adalah kemampuan menggabungkan (crossing) kelompok VHF dan UHF. Dengan adanya Cross Band Repeater yang terpasang pada Repeater maka dihasilkan suara lebih bersih dari gangguan diri-sendiri juga jarak jangkau akan lebih jauh dengan penggunaan energi yang kecil.
\end{abstract}

Kata kunci : Repeater, Cross band repeater (XBR), HT

\section{PENDAHULUAN}

\subsection{Latar Belakang}

Penggunaan perangkat komunikasi bergerak yang saat ini dianggap paling praktis dan ringkas serta cepat dalam penyapaian informasi adalah radio genggam (Handy Transceiver) baik yang bekerja di band VHF (137 MHZ - 171 Mhz) maupun UHF (410Mhz -450Mhz), semakin tinggi frekuensi kanal yang digunakan maka perangkat radio secara keseluruhan akan semakin kecil, namun harganya semakin mahal, berdasarkan pertimbangan seperti diatas itulah, maka komunikasi yang digunakan oleh kalangan tertentu banyak menggunakan radio genggam. Komunikasi radio pada band VHF secara efektif hanya menjangkau sekitar $2-5 \mathrm{~km}$ saja bila tidak mendapat halangan, bila ada gedung atau bangunan lain yang bersifat menyerap energi elektromagnetik, maka jarak jangkau tersebut akan menurun secara drastis, untuk mengatasinya dibangunlah Cross Band Repeater $(X B R)$, yang akan meneruskan informasi yang lemah kepada penerima lain dengan energi yang lebih besar, sehingga kendala komunikasi yang disebabkan berbagai macam gangguan seperti diatas dapat dihilangkan. dalam hal ini dialami dalam komunikasi radio Unit Koperasi dengan kelompok usaha bersama peternak sapi perah (KUBE PSP) Desa Kemiri Kecamatan Jabung Malang, kedua lokasi ini harus dapat dihubungkan dengan komunikasi radio yang tidak boleh terhambat oleh ruang dan waktu, bisa saja dibangun satu repeater yang berkapasitas besar, namun jangkauannya akan semakin luas sehingga informasi yang dikirim akan sampai pada orang yang tidak berhak. Untuk mengatasi kendala tersebut, kami berusaha memberikan solusi dengan membangun dua repeater yang sama.

\subsection{Tujuan}

1. Menghubungkan secara fisik, Desa Kemiri Kecamatan Jabung Malang Melalui Link Radio UHF ke Unit koperasi yang letaknya berjauhan dari letak geografisnya, namun 
dapat dengan mudah melaukan komunikasi aural.

2. Membangun dua (2) stasiun radio pancar ulang (Repeater) masing-masing di Desa Kemiri lokasi KUBE PSP berada dan Unit Koperasi pada band VHF (150-160 MHZ) dengan daya 3 Watt maksimum

3. Membangun Stasiun penghubung Cross Band Repeater (XBR) pada kanal frekwensi band $U H F(430 \mathrm{MHz})$

\section{LANDASAN TEORI}

\subsection{Dasar Repeater}

Repeater bertugas mentransmisikan sinyal yang diterima dari bagian receiver melalui bagian transmitter secara simultan. Tujuan digunakannya repeater adalah untuk menghindari adanya signal loss ketika informasi menempuh jarak yang cukup jauh, atau menemui halangan seperti gunung atau bukit, sehingga memungkinkan untuk tercapainya komunikasi yang lebih efektif. Seseorang dengan perangkat radio handheld seperti handy talkie (disebut juga mobile station) dapat berkomunikasi dengan orang lain yang berada pada jarak yang sangat jauh darinya, dengan memanfaatkan perangkat repeater. Selain itu, alasan lain dari penggunaan repeater adalah kecepatan pengirimannya yang lebih real- time, sehingga repeater sering digunakan untuk berbagai keperluan komunikasi seperti komersial (bisnis), komunikasi darurat (penanggulangan bencana), dan operator radio amatir. Istilah Repeater di Indonesia sudah biasa diterjemahkan oleh para Amatir radio dengan istilah Pancar-Ulang. Bentuk diagram blok Repeater dapat dilihat pada Gambar 2.1.

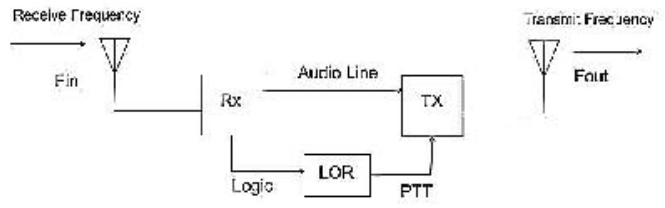

Gambar 2.1. Diagram blok perangkat Repeater

Fin pada gambar tersebut menggambarkan frekuensi pancaran radio yang diterima, sedangkan Fout adalah frekuensi pancaran ulangnya. Biasanya pada standar Amatir Radio, selisih Antara Fin dan Fout adalah $600 \mathrm{KHz}(0,6$ Mhz). Kekuatan Pancar yang dianjurkan adalah sekitar 30 watt, karena bila melebihi daya tersebut banyak kemungkinan justru akan mengganggu sistem penerimanya sendiri (menjadi tidak peka karena terganggu pancarannya sendiri). Demikian juga susunan antenna harus pada level ketinggian yang berbeda. Antena penerima sebaiknya ditempatkan pada ujung tower dan antenna pemancarnya ditempatkan di bawahnya dengan jarak lebih dari 10 meter

Secara umum ada dua jenis repeater, yaitu :

\section{Cross Band Repeater (XBR)}

Cross Band Repeater adalah sistem perangkat repeater yang menggunakan dua band berbeda untuk input dan outputnya. Kebanyakan menggunakan band VHF dan UHF. Input dan output dapat dipakai berbalikan, misal input dari VHF dan memancar ulang di UHF dan sebaliknya. Keuntungan dari XBR adalah kemampuan menggabungkan (crossing) kelompok VHF dan UHF. Kelemahannya adalah, ketika pada satu sisi digunakan, sisi lainnya tidak dapat memasukkan panggilan. Cross Band Repeater berfungsi sama dengan Repeater tetapi mempunyai keunggulan lebih bersih dari gangguan diri-sendiri dan mempunyai band yang berbeda Antara frekuensi masuk dan frekuensi keluarnya. Bila sedang menerima sinyal masuk pada band VHF, maka sinyal yang diterima dipancar ulang pada frekuensi dengan Band UHF atau sebaliknya, menerima di UHF dan memancar di VHF.

Kelemahan pada system Cross Band ini adalah, ketika sedang menerima maka bagian yang lain tidak bias menerima, jadi hanya salah satu yang aktif menerima. Tetapi punya kelebihan juga system ini bias dpergunaka untuk membuat jejaring antar Repeater-Repeater VHF agar terinterkoneksi secara peer to peer. Blok diagram system Cross-Band Repeater ditunjukkan pada Gambar 2.2.

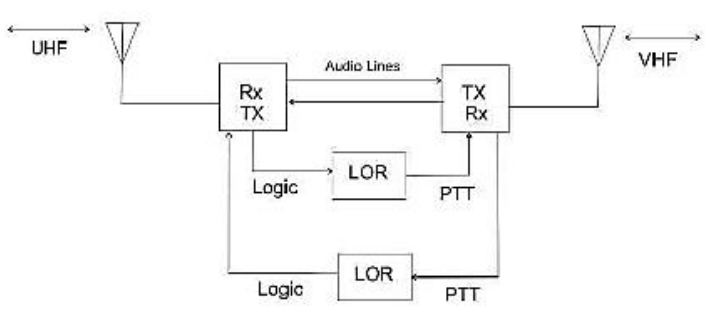

Gambar 2.2. Diagram blok Cross-Band Repeater 
Pada Gambar 2.2 tampak bahwa rangkaian blok yang mirip seperti Repeater tetapi dapat berfungsi secara bolak-balik dua arah (bandingkan dengan Repeater yang hanya satu arah saja). Cross Band Repeater ini sangat berguna dalam penyusunan sistem interkoneksi untuk jejaring Repeater, misalnya jejaring Jawa-Bali. Dengan adanya jejaring Jawa Bali ini, hanya dengan perangkat HT yang berdaya pancar di bawah 1 watt, mampu berkomunikasi dengan lawan bicara yang berada pada jarak ribuan kilometer.

\section{Same Band Repeater}

Adalah sistem perangkat repeater yang menggunakan band yang sama untuk input dan output. Biasanya digunakan band VHF untuk input dan output atau UHF untuk input dan output. Kelebihan dari repeater jenis ini adalah bias menggunakan antena berjenis sama untuk menerima dan mengirimkan data, sehingga apabila dipasangkan duplexer bias menggunakan satu antena saja. Secara fisik, umumnya kedua jenis repeater tersebut tidak dapat dipindahkan dari tempatnya, sehingga harus berada di stasiun tetap (base station). Namun ada jenis repeater lain yang dapat dipindahkan, yaitu mobile repeater (mobile $X B R$ ). Repeater ini biasa dipasang di mobil, dengan sumber daya mandiri dan antenna yang dipasang pada mobil. Keuntungan dari penggunaan repeater ini adalah mampu bergerak cepat pada posisi tertentu untuk membantu sistem komunikasi petugas di lapangan dengan daya yang lebih kuat daripada HT.

\subsection{Perancangan Sistem Repeater}

Sebelum melakukan perancangan sistem repeater, perlu diketahui pula prinsip kerja dan bagian-bagian penting mengenai suatu repeater. Ketika tombol Push To Talk (PTT) pada Handy Talkie ditekan dan memancarkan sinyal informasi dengan frekuensi A. Bagian receiver dengan frekuensi yang sama akan menerima informasi tersebut. Ketika bagian receiver menerima sinyal input, maka Carrier Operated Relay (COR) langsung mengaktifkan bagian transmitter untuk memancarkan kembali informasi yang telah diterima tersebutdengan frekuensi berbeda (disebut frekuensi B).
Informasi yang telah dipancarkan olehtransmitter ini diterima oleh HT lain di lapangan yang juga memiliki frekuensi B. Diagram blok dari sistem repeater tampak pada Gambar 2.3.

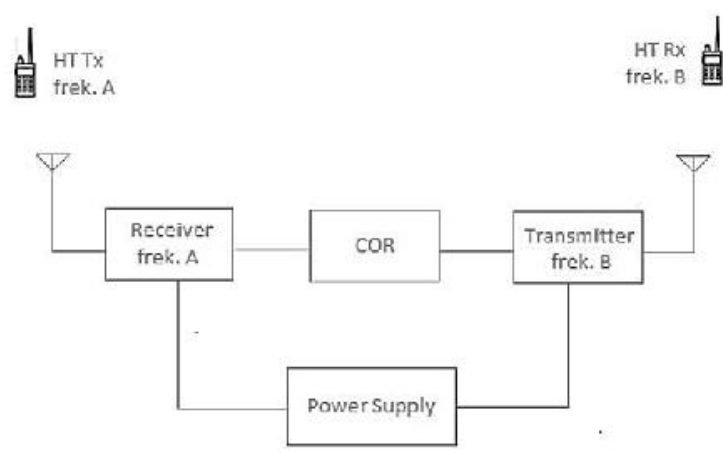

Gambar 2.3. Diagram blok sistem repeater secara umum

\subsection{Antena}

Antena dalam komunikasi radio adalah peralatan penting yang mengubah getaran- getaran listrik menjadi getaran-getaran elektromagnetik yang merambat kesegala penjuru sesuai dengan kondisi geografis media rambatannya, dan frekuensi kerja yang dioperasikan, apakah berada di HF, VHF, UHF atau bahkan SHF (Super High Frequency).

Pada umumnya antena dapat dikelompokkan dalam tiga (3) golongan utama, yaitu :

1. Antenna Omni Dirrectional

2. Antenna Birectional

3. Antenna Dirrectional

\subsubsection{Antena Omni Directional}

Adalah antenna yang digunakan untuk mengirimkan getaran radio kesegala arah, umumnya antena seperti ini dipasang secara vertikal sehingga bila pola radiasinya dilihat dari pandangan atas, terlihat membentuk lingkaran dengan titik pusat lingkaran adalah unit antennanya. Antenna Omni Dirrectinal yang ideal dan mendasar adalah antenna dengan istilah Ground Plane seperti pada gambar 2-4.

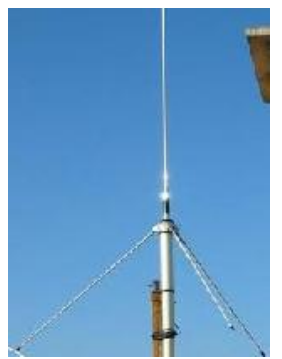

Gambar 2-4. Antena Omni Directional 
Dimensi antenna ini menggunakan elemen penghantar yang panjangnya seperempat panjang gelombang (1/4 $\square$ ) untuk masing-masing elemen antenanya yang berjumlah 4 buah, 1 buah sebagai radiator, dan 3 buah sebagai refelctornya.

\subsubsection{Antenna Bidirrectional}

Sedangkan antenna bidirrectional3 adalah unit antenna yang hanya memancarkan dalam dua arah yang bertolak belakang, jenis antena ini terkenal dengan nama antenna Dipole, dikatakan demikian antenna ini memang terdiri dari dua kutub, ada yang dari jenis open dipole, dengan impedansi kutubnya sebesar $75 \Omega$, namun ada juga yang berupa Dipole lipat, atau disebut juga dengan Folded Dipole, dengan impedansi kutubnya sebesar $300 \Omega$.

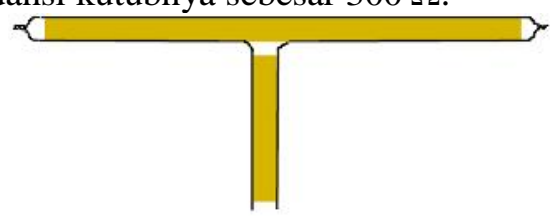

Gambar 2-5. Antena Dipole

\subsubsection{Antenna Dirrectional}

Antenna Dirrectional adalah jenis antenna yang digunakan hanya untuk mengirimkan getaran-getaran radio dalam satu arah saja, sehingga sering disebut dengan antenna pengarah. Antenna jenis ini memang dirancang untuk mengarahkan sebesar-besar energi gelombang radio hanya pada satu arah, sehingga dalam arah balik dipasangkan sebuah elemen tambahan berupa elemen pemantul atau reflector element, yang dimensinya merupakan yang paling panjang dibandingkan elemen-elemen antenna yang lain. Umumnya antena pengarah ini terdiri dari 2 bagian utama antenna yang disebut :
a. Elements antenna
b. Boom antenna (batang Utama) menjadi beberapa bagian, yaitu :
a. Elemen Driven (DE)
b. Elemen Dirrector (DIR)
c. Elemen Reflector (REFL)

Sedangkan elemen antenna dapat dibagi lagi

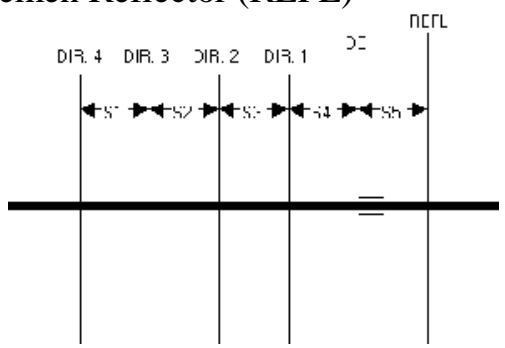

Gambar 2.6. Antenna Pengarah

\subsection{Filter}

Filter yang digunakan dalam kelengkapan sebuah repeater dapat dipisahkan dalam 2 (dua) jenis yang berbeda. Sebuah filter digunakan sebagai band pass filter dan sebuah lagi dari jenis band nocth filter. Kedua jenis filter tersebut merupakan filter yang cara kerjanya kebalikan satu terhadap yang lain. Bila Band pass filter sesuai dengan namanya, melewatkan frekuensi yang hanya diperlukan saja, biasanya frekuensi tersebut berada ditengah dari kondisi yang akan dilewatkan, kemampuan untuk melewatkan frekuensi sebuah band pass filter sangat tergantung dari lebar band (pita) frekeunsi yang dapat dilewatkan, dan faktor ini juga ditentukan lagi oleh nilai faktor Q (Quality) dari kumparan yang digunakan dalam salah satu komponen filter tersebut, semaki besar nilai $Q$ dari sebuah kumparan, maka semakin sempit pita frekuensi yang dilewatkannya. Hal ini dapat dirumuskan sebagai :

$$
Q=\frac{R}{X_{L}}
$$

Dalam aplikasinya, filter untuk mengoptimalkan Repeater terdapat 2 (dua) tipe yang berbeda, yaitu:

1. Diplexer adalah filter dengan Bandpass filter (BPF) dan nocth filter (NF), masing-masing menggunakan sebuah antena sebagai antena penerima (input) dan pemancar (output)nya (Gambar 2.7).

2. Sedangkan Duplekser adalah penggabungan 2 (dua) macam filter seperti diatas dengan menggunakan dua buah antena yang sama, seperti dalam gambar 2.8

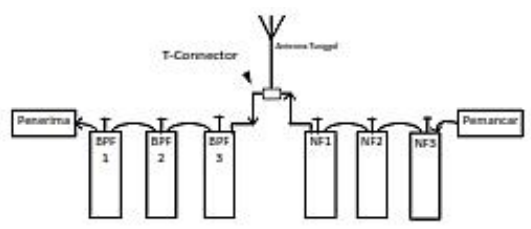

Gambar 2-7. Antena Diplexer

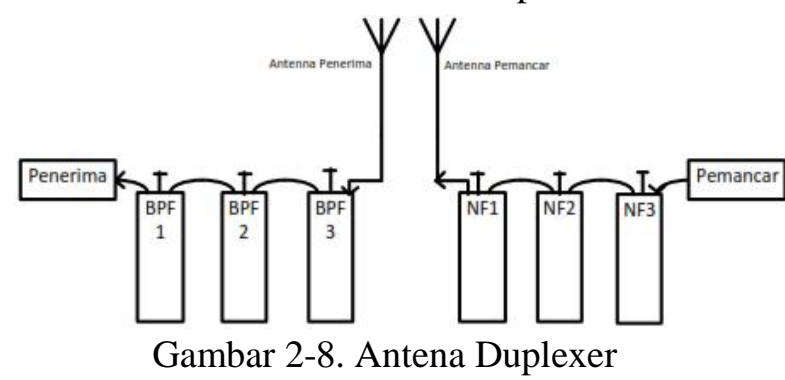

Bila sebuah duplekser digunakan, masalah insertion loss merupakan komprominya. Tetapi 
beberapa insertion loss lebih besar dari Offset yang menggunakan sebuah antenna baik sebagai pemancar (Tx) maupun sebagai penerima ( $\mathrm{Rx})$ sekaligus. Pengunaan sebuah antenna berdampak pada pola pancaran yang mirip pada pancaran maupun penerimaannya. Duplekser akan terus dipergunakan oleh beberapa lembaga komersial yang meng-operasikan repeater untuk beberapa tahun terakhir ini. Sejumlah besar dari system tersebut menggunakan pemisahan frekuensi dua persen atau lebih diantara kanal input dan outputnya. Repeater VHFg bekerja di 2 meter band $( \pm 150 \mathrm{MHz})$ memiliki pemisahan hanya 0,4 persen, atau $600 \mathrm{kHz}$. Pengurangan dalam pemisahan frekuensi akan menyediakan pengisolasian yang lebih baik, yang tentu saja lebih sulit dalam pengoprasiannya. Sebuah duplekser harus memenuhi beberapa persyaratan dasar. Ia harus dapat meredam gelombang pemancar pada bagian penerimanya, hal ini untuk mencegah terjadinya penerimaan signal yang berlebihan pada pesawat penerima, yang akhirnya dapat menyebabkan penurunan sensitivitas penerimanya. Sebuah repeater harus dapat juga meredam signal-signal noise atau yang biasa disebut dengan spurious energy dari pemancar (Tx) yang aktiv atau dekat dengan frekuensi penerima (Rx). Sebagai tambahan, sebuah duplekser harus menyediakan kesesuaian impedansi antara Tx - antenna dan Rx. Bila anda mempunyai masalah untuk membayangkan fungsinya, Gambar 2.10 dapat membantu. Output Pemancar pada frekeunsi $146.940 \mathrm{MHz}$ yang mengalir dari C ke D harusnya tidak boleh teredam. Sebaliknya, energy dari pemancar ini harus teredam semaksimal mungkin diantar titik B dan A.

Duplekser seksion 2 harus meredam nois dan signal-signal dedikat frekuensi input Penerima yang 146.340 Mhz. Untuk penerimaan yang baik, noise dan signal pengganggu (spurious signal) harus lebih kecil dari $-130 \mathrm{~dB}$ ( $0 \mathrm{~dB}=1$ miliwatt pada $50 \mathrm{Ohm}$ ). Nois pemancar $600 \mathrm{kHz}$ dari frekuensi pembawa adalah $80 \mathrm{~dB}$ dibawah daya outputnya. Untuk daya 60 Watt $(+48 \mathrm{dBm})$, noisenya $-32 \mathrm{dBm}$. Duplekser harus dapat memberikan selisih -32 dan $-130 \mathrm{dBm}$, atau -98 $\mathrm{dBm}$.

Untuk signal penerima. Pertama dari semuanya, signal yang diterima harus mengalir dari titik B ke A dengan redaman seminim mungkin. Duplekser Seksi-1 memberikan redaman yang cukup untuk energy yang dipemancarkan untuk mencegah sang penerima menjadi overload. Untuk penerima umumnya, signal transmitter harus kurang dari $-30 \mathrm{dBm}$ sebagai kebutuhannya. Hal ini dilakukan oleh duplekser seksi-1 untuk menjadikan selisih dengan output transimitter sebesar $+48 \mathrm{dBm}$ dan titik overload penerima yang $30 \mathrm{dBm}$. Satu hal bahwa beberapa duplekser berada dalam kebersamaan yang menggunakan koaksial cavity dengan $Q$ yang tinggi. Pembebanan $\mathrm{Q}$ sebuah cavity mempengaruhi konduktivitas elektrik dan redaman dielektrik. Kerugian permukaan dapat dikurangi dengan pelapisan perak pada permukaannya, walaupun tembaga yang bersih sudah mencukupi. Duplekser cavity dengan dielektrik udara merupakan duplekser yang banyak digunakan oleh kalangan amateur.

\section{MATERI DAN METODE PELAKSANAAN Kerangka Pemecahan Masalah}

Penerapan yang dilakukan disini menerapkan metodologi perancangan dan pembuatan secara terpadu antara teknologi komunikasi radio dan teknologi elektronika kendali. Peralatan yang digunakan merupakan penggabungan 2 (dua) perangkat komunikasi Radio genggam yang masing-masing bekerja pada Band VHF, yang sebuah digunakan sebagai penerima dan sebuah lagi digunakan sebagai pemancar dengan dua kanal yang berbeda sehingga kedua unit radio dapat bekerja secara simultan.

Untuk mencegah terjadinya gangguan cakap silang antara Desa Kemiri Kecamatan Jabung Malang dan Unit koperasi yang menggunakan alokasi frekuensi yang sama, kami merencanakan untuk memasang peralatan Radio Link pada band UHF di Desa Kemiri Kecamatan Jabung Malang untuk memisahkan dan menghindari gangguan akibat cakap silang tersebut

Dengan mengggunakan filter lolos tengah (Band Pass Filter) masing-masing sebanyak dua buah untuk radio penerima (Receiver $=\mathrm{Rx}$ ) dan dua buah lagi untuk pemancarnya (transmitter $=\mathrm{Tx}$ ), maka diharapkan dapat memberikan hasil yang maksimal dalam proses komunikasi suara tersebut. 


\section{Realisasi Pemecahan Masalah}

Penerapan IPTEKS ini melibatkan beberapa unit terkait yang merupakan unsur- unsur sumberdaya manusia dan sumberdaya informasi. Dari segi sumber daya manusia (SDM), kegiatan ini melibatkan instansi yang mewakili Program Studi, yaitu Teknik Listrik DIII dan Teknik Informatika S-1, sedangkan dari masyarakat diwakili oleh Personil dari Unit Koperasi dan beberapa peternak sapi

\section{Khalayak Sasaran Antara Yang Strategis}

Khalayak sasaran yang ingin dilibatkan dalam kegiatan ini adalah personil mahasiswa, beberapa personil dari Unit Koperasi dan beberapa peternak sapi.

\section{Metode Yang Digunakan}

1. Memodifikasi Radio genggam (Handy Transceiver $=$ HT) yang difungsikan masing-masing sebagai repeater (stasiun pancar ulang) dengan penggabungan 2 (dua) perangkat komunikasi Radio genggam yang bekerja pada Band VHF dan UHF, sehingga yang satu unit digunakan sebagai penerima dan sebuah lagi digunakan sebagai pemancar dengan dua kanal yang berbeda sehingga kedua unit radio dapat bekerja secara simultan.

2. Memberikan pengarahan cara pemakaian penggunaan alat repeater (stasiun pancar ulang) agar dapat dihasilkan yang maksimal dan tanpa mengalami hambatan dalam berkomunikasi.

\section{HASIL DAN PEMBAHASAN}

\section{Rangkaian Filter}

Sebuah resonator seperempat lambda dipilih untuk perancangan duplekser ini. Dimensi konduktor yang berada ditengah tabung dapat disetel dengan memutar batang pendorong, yang dapat ditala pada frekeuensi kerjanya. Energi terhubung kedalam dan keluar rangkaian tertala melalui untai kopling melewati piringan bagian atas. Cavity difungsikan sebagai rangkaian resonan seri. Bila sebuah kapasitor atau inductor dihubungkan pada rangkaian resonan seri, sebuah anti resonan notch akan dihasilkan, dan frekuensi resonansinya akan bergeser. Jika sebuah kapasitor ditambahkan, suatu notch muncul dibawah frekuensi resonansinya. Sedangkan bila ditambah-kan sebuah inductor akan membuat notch terjadi diatas frekuensi reonansinya, dan nilai salah satu komponen akan ditentukan oleh spasi antara notch dan frekuensi reosnansinya. Gambar 4.1 memperlihatkan karakteristik Bandpass Filter cavity dengan element shunt. Dengan cavity yang di-tala pada frekuensi $146.940 \mathrm{MHz}$, dan sebuah kapasitor Shunt dihubungkan dari titik input ke titik outputnya, maka sinyal dengan frekuensi 146.340 MHz akan mengalami redaman sebesar $35 \mathrm{~dB}$.

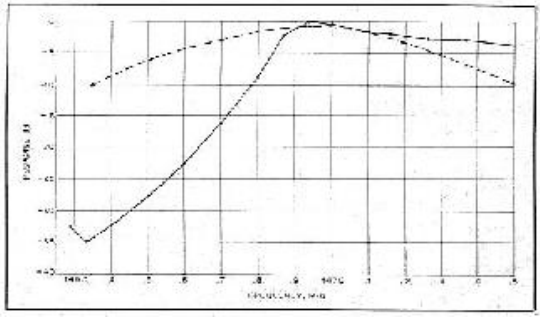

Gambar 4.1. Renspons Frekuensi Sebuah Filter Tabung

Cavity yang dipasangkan dengan sebuah induktansi diantara input dan ouputnya, dan ditala pada frekuensi $146.340 \mathrm{MHz}$, redaman akan terjadi pada frekuensi diatasnya, yaitu pada frekuensi 146.940 MHz sebesar $35 \mathrm{~dB}$.

Sedangkan besarnya Insertion Loss untuk kedua model cavity tersebut sama-sama $0,4 \mathrm{~dB}$. Tiga buah cavity dengan kapasitor shunt yang ditala pada frekuensi $146.940 \mathrm{MHz}$ dan dihubungkan bersama melalui kabel koaksial pendek, maka redaman sinyal pada frekuensi $146.340 \mathrm{MHz}$ akan menjadi sekitar $100 \mathrm{~dB}$, sementara insertion lossnya menjadi $1,5 \mathrm{~dB}$. Kurva yang terjadi pada enam buah cavity yang difungsikan sebagai duplexer dapat diperlihatkan seperti pada Gambar 4.2 berikut.

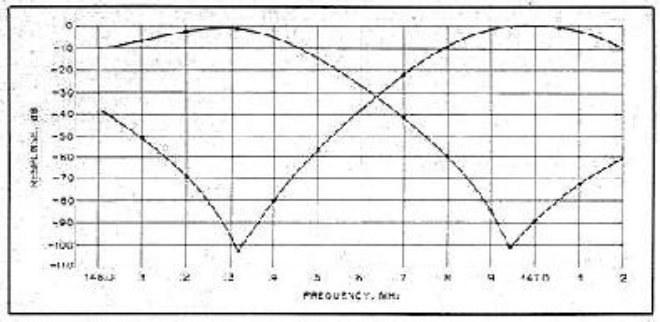

Gambar 4.2. Kurva Pada Enam Buah Sebagai Duplexer 


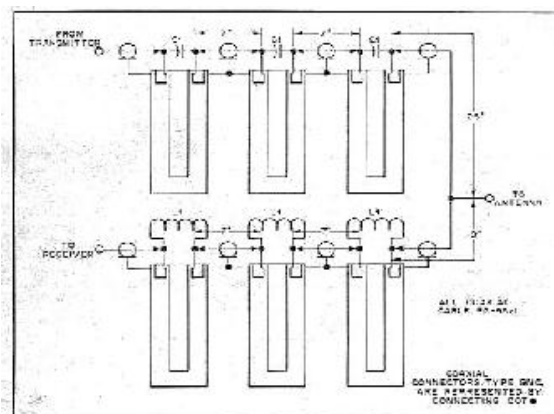

Gambar 4.3. Diagram Rangkaian 6 buah Duplekser Cavity

\section{Konstruksi}

Pekerjaan kecil yang harus dilakukan adalah menutup bagian atas tabung Cavity Filter dengan lempengan (plat) kuningan, bahan kuningan ini digunakan karena mudah dilakukan pekerjaan mekaniknya, selain itu, dalam pekerjaan penyolderan dapat pula dilakukan dengan mudah, dalam hal ini penyolderan sudah dapat menghasilkan pekerjaan yang halus dengan solder listrik berdaya 150 Watt. Bagian atas (tutup) dari bahan kuningan ini dipasangkan kapasitor (C1) variable secara serial terhadap komponen coupling loop untuk filter Cavity pada bagian input (Rx). Sedangkan filter cavity output dapat dipasangkan sebuah induktor yang dalam Gambar 4.4 sama sekali tidak terlihat sebagai sebuah kumparan (L1).

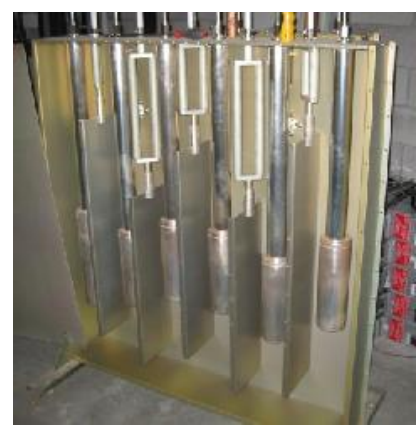

Gambar 4.4 Konstruksi Enam Buah Filter Cavity

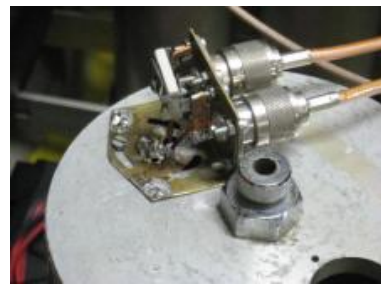

Gambar 4.5 Pemasangan Dua macam Penghantar

Pipa tembaga DWV digunakan untuk konduktor luar cavity. Lihat Gambar 4.5. Ketebalan tabung Cavity bagian luar hanya berkisar $1,5 \mathrm{~mm}$ saja, sedangkan diameter tabungnya sendiri kami menggunakan pipa galvanis dengan diameter 41/8inc atau sekitar $10,5 \mathrm{~cm}$. Panjang tabung bagian luar ini diperkirakan dapat mengakomodir seperempat panjang gelombang dari frekuensi pada band VHF, yaitu sekitar $57,1 \mathrm{~cm}$ perbagian tabung cavity. Konduktor bagian dalam dapat menggunakan pipa tembagai (copper) yang berdiamater sekitar $3,5 \mathrm{~cm}$ atau 1 3/8inci.

Seluruh potongan tersebut diperlukan sebanyak 6 (enam) buah, tiga buah sebagai filter lolos tengah (Bandpass Filter) dan tiga buah lagi digunakan sebagai filter Notch (filter penolak).

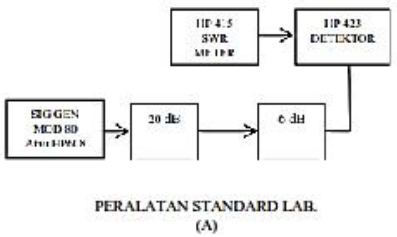

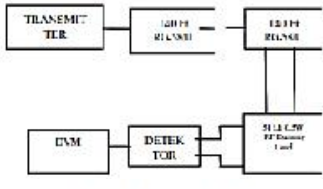

PERALATAN SEDERHAN
Gambar 4.6 Duplekser Dapat di Tala Dengan

Dua Metoda Pengukuran.

\section{Pengendali}

Untuk mengendalikan repeater yang berisi dua buah pesawat VHF yang berfungsi sebagai Penerima (Rx) dan Pemancar (Tx) dalam waktu yang bersamaan, diperlukan sebuah rangkaian sederhana yang dapat mengkatifkan radio Pemancar bila ada sinyal yang diterima dari Rx, seperti diketahui, sebuah pesawat penerima VHF bila tidak mendapat masukan sinyal, rangkaian amplifiernya akan dibungkam oleh sebuah rangkaian elektronik yang disebut rangkaian Squelch.

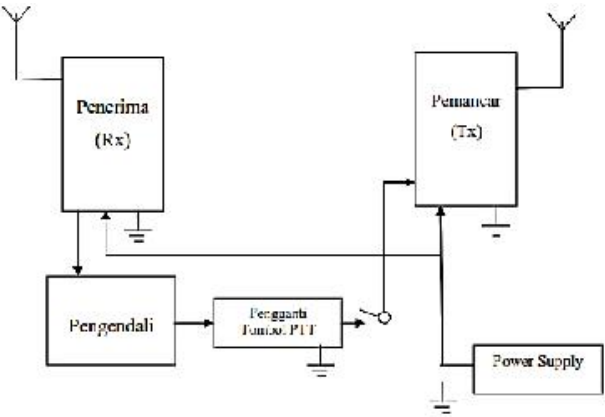

Gambar 4.7 Diagram Blok Repeater 


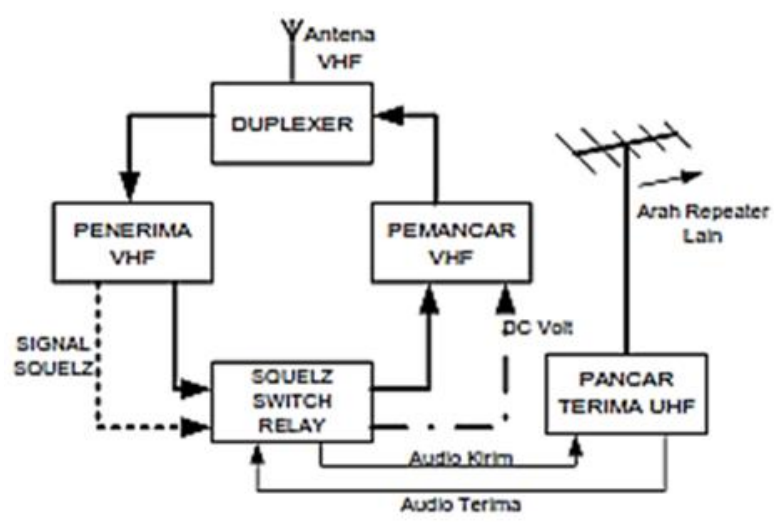

Gambar 4.8. Satu Unit Repeater Setelah Menggunakan Link UHF

\section{Penyetelan Menggunakan Peralatan Sederhana}

Memerlukan spurious signal yang minimum, kalau tidak akan didapat penunjukan salah yang cukup besar. DVM (DIGITAL VOLT METER) yang digunakan harus dapat membaca dengan baik tegangan kurang dari 0,5 Volt pada skala penuh. Probe RF harus dapat mengolah sinyal dengan baik pada frekuensi $100 \mathrm{MHz}$ atau lebih. Potongan koaksial RG58/U digunakan sebagai attenuator. Redaman pada kabel sepanjang $140 \mathrm{ft}$ mendekati $10 \mathrm{~dB}$ dan dapat membantu untuk mengisolasi transmitter dalam masalah mismatch selama dilakukannya tuning.

Mengatur transmitter pada frekuensi input repeater dan hubungkan titik P dan Q. Pastikan pembacaan pada DVM (DIGITAL VOLT METER) antara 1 dan 3 volt. sebuah kapsitor shunt antara $\mathrm{P}$ dan $\mathrm{Q}$, kemudian mengatur batang pengatur cavity untuk pembacaan minimum pada DVM (DIGITAL VOLT METER). Besarnya tegangan yang terbaca sekitar 0,01 hingga 0,05 Volt saja. Dari sini dapat diketahui besarnya rejection dalam satuan $\mathrm{dB}$ dengan rumus $20 \log \mathrm{V} 1 / \mathrm{V} 2$, sehingga didapat nilai minimal $-35 \mathrm{~dB}$.

Dengan melakukan pemeriksaan insertion loss dengan menggunakan frekuensi output repeater dan catat pembacaan DVM (DIGITAL VOLT METER) dengan rangkaian In dan Out cavity, didapatkan peredam (attenuator) 0,5dB dengan menggunakan potongan kabel koaksial RG-58/U sepanjang $7 \mathrm{ft}(2,13 \mathrm{~m})$. Potongan kabel ini dapat digunakan untuk pengujian kalibrasi probe detector dan DVM (DIGITAL VOLT METER). Cavity lain yang menggunakan inductor shunt dapat ditala dengan cara yang sama, namun dengan frekuensi kebalikannya. Jika dicoba untuk menala dua atau lebih cavity yang dihubungkan bersamaan, noise transmitter dapat menyebabkan pembacaan menjadi kecil. Dengan kata lain, berarti mengecil redamannya.

\section{Hasil}

Duplekser secara mendasar bekerja pada daya input sekitar 150 Watt, tetapi dapat dioperasikan sampai 300 Watt. Pelapisan dengan bahan perak pada sisi bagian dalam tabung cavity merupakan cara terbaik jika daya inputnya melebihi 150 Watt. Selain itu, sebuah duplekser yang dilapisi bahan perak akan memiliki nilai insertion loss dibawah $1 \mathrm{~dB}$, dan rejection lebih dari -100dB. Sedangkan cavity yang tidak dilapisi bahan perak harus dilakukan perawatan secara berkala paling tidak setiap 2 (dua) tahun sekali, dengan membersihkan dan menala ulang.

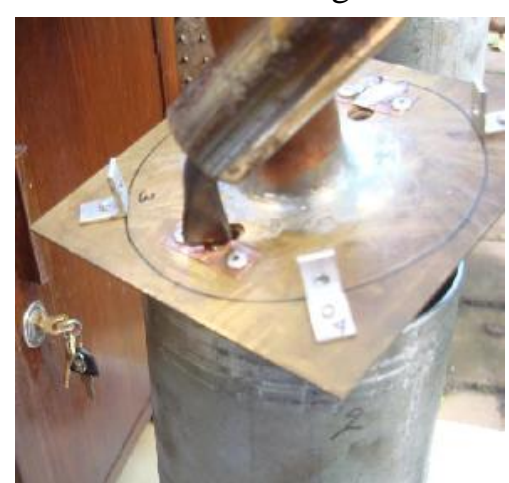

Gambar 4.9. Tahap Pemasangan Coupling Loop

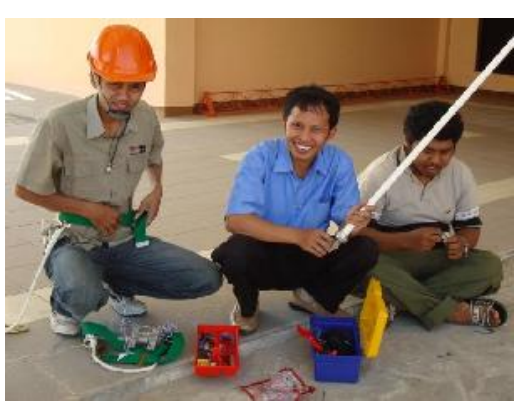

Gambar 4.10. Persiapan Pemasangan Antena Repeater 


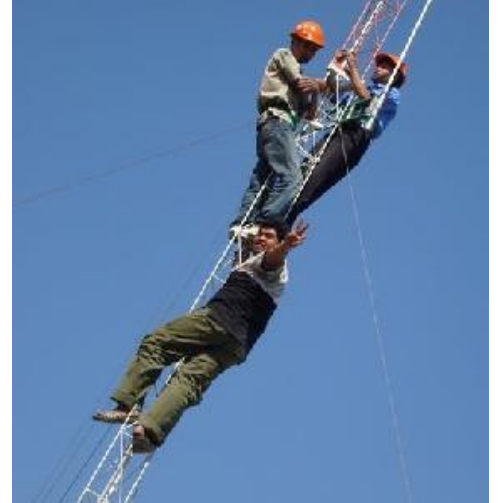

Gambar 4.11. Tahap Pemasangan Antena Repater

\section{KESIMPULAN DAN SARAN \\ Kesimpulan}

Setelah dilakukan uji coba dan percobaan, dapat disimpulkan bahwa :

1. Pada jarak $8 \mathrm{~km}$ dari titik radio Link, sinyal penerimaan yang diukur pada rangkaian penala perangkat penerima masih diatas $1 \mu$ Volt.

2. Pada jarak $8 \mathrm{~km}$ dari titik radio Link, kualitas audio yang dihasilkan masih berada diatas $1 \mathrm{mVolt}$ dengan noise masih dibawah ambang mengganggu, yaitu sekitar $5 \%$ dari amplitudo maksimum audio yang dihasilkan pada nada $1 \mathrm{kHz}$.

3. Dengan pemasangan Cross Band Repeater (Xbr), maka komunikasi antara kedua lokasi tidak akan terganggu.

\section{Saran}

1. Kabel dengan pelindung ganda hendaknya digunakan secara penuh pada system.
2. VSWR antenna tidak boleh lebih besar dari 1,2:1 untuk repeater yg baik.

3. Sekat/isolasi yang baik antara Tx dan Rx pada repeater merupakan hal yang mendasar.

4. Antena harus terpisah paling tidak $4 \mathrm{kali}$ panjang gelombang atau lebih pada repeater.

5. Seluruh konduktor yang dekat dengan antenna harus tersambung dengan baik dan di ground untuk menghilangkan noise.

6. Saluran transmisi harus tersambung dengan baik dan aman pada tower atau tiang.

7. Setiap cavity filter atau pasangannya dapat digunakan untuk memperbaiki unjuk kerja antenna yg terpisah atau lokasi repeater lain.

8. Filter cavity yang terpisah dapat digunakan untuk mengatasi masalah intermodulasi.

\section{DAFTAR PUSTAKA}

[1]. Mudrik Alaydrus. Antena Prinsip dan Aplikasi. Graha Ilmu, 2011

[2]. Thomas, L.F, 1992, Electronic Devices. Merrill Publishing Company, USA

[3]. ARRL, Amateur Radio Hanbook, Eighty-Fourth Edition Published by: ARRL - the national association for Amateur Radio Newington, CT 06111 USA

[4]. Louis E. Frenzel Jr, Principles of Electronic Communication System, $3^{\text {rd }}$ Edition, McGraw Hill, 2008 